\title{
Zakour Forest fire risk map assessment in the commune of Mamounia (Mascara, Algeria)
}

\author{
Djamel Anteur ${ }^{1} \bowtie$, Abdelkrim Benaradj $^{2}$, Youcef Fekir $^{3}$, Djillali Baghdadi $^{4}$ \\ ${ }^{1}$ Tahar Moulay University of Saida, Research Laboratory of Water Resources and Environment, \\ BP 138 cité ENNASR 20000, Saida, Algeria, e-mail: djanteur@yahoo.com \\ ${ }^{2}$ Salhi Ahmed University Center of Naama, Laboratory of Sustainable Management of Natural Resources in Arid \\ and Semi-Arid Areas, BP 66, Naâma, Algeria \\ ${ }^{3}$ Mustapha Stambouli University of Mascara, Research Laboratory on Biological Systems and Geomatics, \\ Avenue Cheikh El Khaldi, Mascara 29000, Algeria \\ ${ }^{4}$ Ahmed Zabana University Center in Rélizane, Bourmadia, Relizane, Algeria
}

\begin{abstract}
The great forest of Zakour is located north of the commune of Mamounia (department of Mascara). It is considered the lung of the city of Mascara, covers an area of 126.8 ha. It is a forest that is subject to several natural and human constraints. Among them, the fires are a major danger because of their impacts on forest ecosystems.

The purpose of this work is to develop a fire risk map of the Zakour Forest through the contribution of geomatics according to natural and anthropogenic conditions (human activities, agglomeration, agricultural land) while integrating information from ground on the physiognomy of the vegetation.

For this, the creation of a clearer fire risk map to delimit the zones potentially sensitive to forest fires in the forest area of Zakour. This then allows good implementation of detection management plans, for better prevention and decision-making assistance in protecting and fighting forest fires.
\end{abstract}

\section{KeY WORDS}

fire, geomatics, forest, risk, Zakour, Mascara

\section{INTRODUCTION}

For several decades, the Algerian forest, like all the forests of the Mediterranean region, has been subjected to multiple attacks, both climatic and anthropogenic. Among these attacks that accentuate deforestation: fires, drought, overgrazing, agricultural abandonment, erosion, phytosanitary problems, attacks on the processionary caterpillar, lack of maintenance and cultural care, the strong pressure from forest-bordering populations, land clearing, increased urbanisation, tourist pressure and illegal logging and firewood harvesting (Louni 1994; Benderradji et al. 2006; Arfa 2008; Alexandrian 2008; Khader et al. 2009; Bensouiah 2004; Mihi 2012; Laala 2016; Talbi et al. 2017; Chiali-Charif 2018).

But, fires constitute the most destructive permanent danger of forest that threatens these ecosystems, 
whether by their influence on the composition of species and forest cover or the threat they represent for human societies (Ghennai 2015).

Globally, 350 million ha of natural areas are destroyed by fire every year, or $9 \%$ of the total area of forests and non-forest areas (FAO 2007).

According to Vélez (1999), fire is, in Mediterranean forests as in many parts of the world, a chronic, recurrent phenomenon whose intensity seems to be increasing. The Mediterranean forest covers around 85 million ha in 2010 , or $2 \%$ of the world's forest area (FAO 2013). For the Mediterranean Basin, forest fires constitute a main permanent threat of forest destruction, especially in summer; more than 55,000 fires run on average each year ravaging from 700,000 ha to 1 million ha of Mediterranean forest, causing enormous ecological and economic damage, as well as loss of human life. The environmental consequences and the negative socio-economic effects of fires oblige the riparian countries to make intense efforts both in terms of prevention and extinction (Vélez 1999; Gouiran 1999; Jappiot et al. 2003; Martinez et al. 2004; Dimitrakopoulos and Mitsopoulos 2006; Maddou 2016; Chiali-Charif 2018).

In Algeria, forests occupy an area of around $4,100,000$ ha, i.e. less than $2 \%$ of the country's area (Mazali 2003; DGF 2018). It is mainly composed of forest species such as the Aleppo pines; oak cork; holm oak; Junipers and others (Thuja, eucalyptus and various) (ONS 2015). Like the countries around the Mediterranean, Algeria is witnessing an intense deterioration of its forest heritage (Ferka Zazou 2006). Fires constitute the most devastating factor of degradation of the Algerian forest; nevertheless, each year more than 36,000 ha are crossed by fires that remain very frequent in the summer period (Louni 1994; Madaoui 2002; Missouni et al. 2002; Benhanifia et al. 2004; Meddour-Sahar et al. 2008; Khader et al. 2009; Berrichi et al. 2013; Mezrag and Ziane 2013; Meddour-Sahar and Bouisset 2013; MADRP 2015; Hamdach and Bourazza 2016; Souidi and Benbakar 2017; Talbi et al. 2017; Sahar et al. 2018; Chiali-Charif 2018; Talbi 2019).

At the regional level, the burned area is unevenly distributed over the three regions of Algeria. The northeast region with $50.06 \%$ is the most affected, with an area of burned forest formation of 86,246 ha, the northcentral region of the country comes second with $28.21 \%$ over an area of 44,300 ha and finally, that of the northwest with $21.73 \%$ over 24,725 ha (Arfa et al. 2009 ; DGF 2018).

At the local level, at the level of the department of Mascara, the forest massifs cover an area of 161,464 ha. This forest heritage is currently weakened by a large number of natural and human factors, but fires remain the main most devastating and devastating risk of the forest. An area of 220 ha was covered by forest fires during the period from June 1 to the end of September 2019 , because the burnt areas observed on the ground show that the remaining forest cover is likely to disappear if there is no appropriate protective measure (C.F Mascara 2019).

This concerns the "Zakour forest" study area: is considered to be the lung of the city of Mascara, of great ecological and socioeconomic importance extending over an area of several hectares, is faced with a serious threat of fire.

The objective of this work is the development of a fire risk map of the Zakour forest in the commune of Mamounia (Mascara), which then provides a good reference for detection, protection and control.

\section{Material AND methods}

\section{Geographic location of the study area}

The forest of Zakour is located north-east of Mamounia (Daïra d'Aïn Fares) on the edge of the National Road No.7, at $2 \mathrm{~km}$ outside the capital of Mascara, the subject of our study. It is characterised by mountainous terrain at an altitude of $686 \mathrm{~m}$. It is located between longitudes $0^{\circ} 8^{\prime}$ and $0^{\circ} 0^{\prime}$ ' East and latitudes $35^{\circ} 26^{\prime}$ and $35^{\circ} 26^{\prime}$ north (Fig.1). The forest of Zakour is Mediterranean type, covers an area of 126.8 ha, very diverse in species, oak is the main species as well as other species such as Aleppo pine, eucalyptus, undergrowth species and secondary species.

The Zakour forest is increasingly threatened, facing serious degradation problems. Forest fires are unfortunately a very worrying threat for the inhabitants of the region. It is one of the sites most exposed to the risk of forest fire on the scale of the forest heritage of the department of Mascara. In fact, more than 20 ha of forest and brush were ravaged by fire during the summer season (C.F Mascara 2019). 

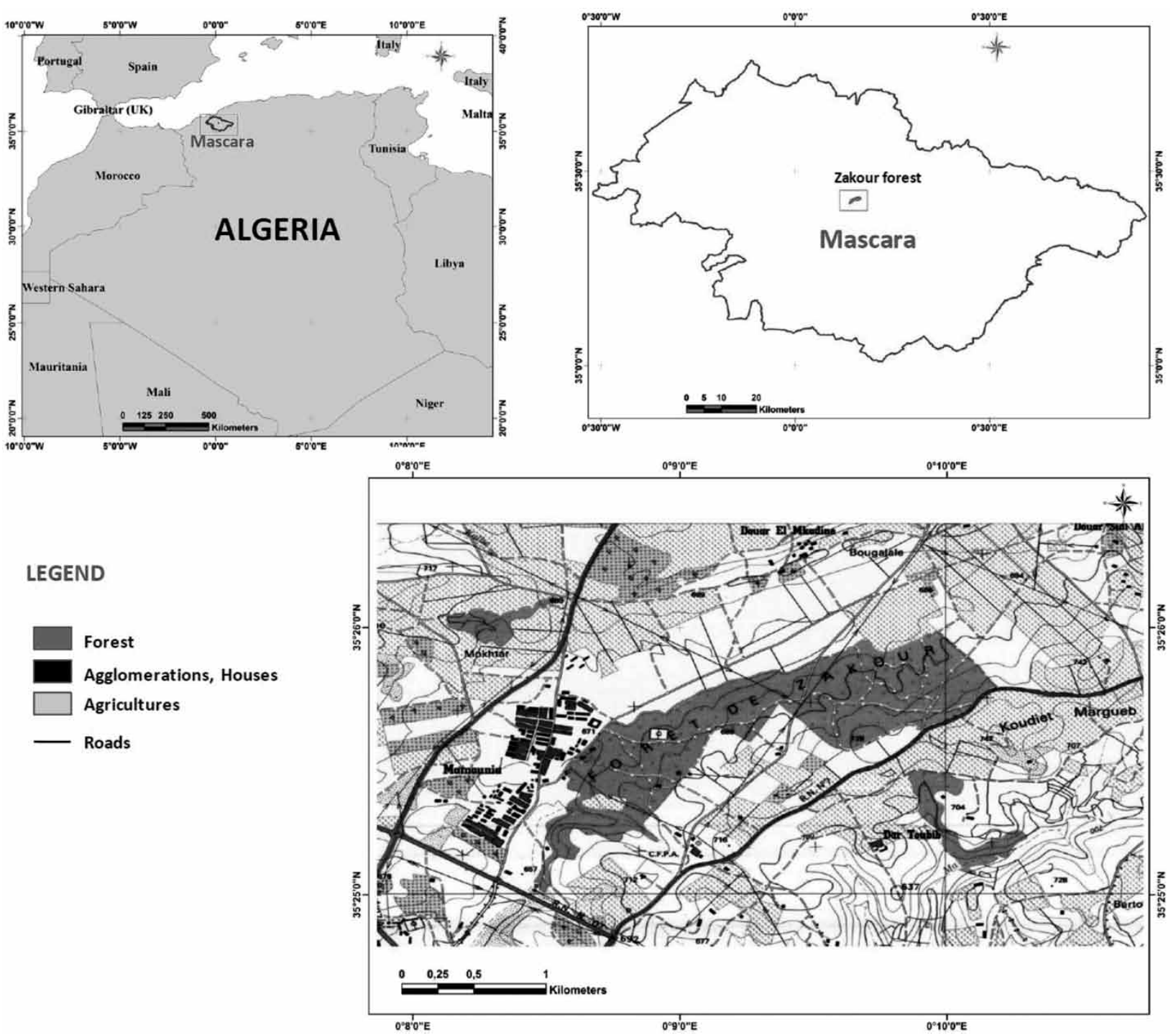

Figure 1. Geographical location of the Zakour forest (Mamounia - Mascara)

On the climate level

The climate of the Mascara region is semi-arid to humid. The average rainfall is around $370 \mathrm{~mm} /$ year. During this same period, the average temperature and the maximum annual average temperature are, respectively, 17.1 and $43.5^{\circ} \mathrm{C}$. The climate is Mediterranean, with a tendency to semi aridity. Weather changes and rainfall show up mainly in late fall and early spring. At the level of the northern plains, the influence of sea winds regulates the rains for part of the year. We also note the presence of very thick fog at the end of spring. The presence of sirocco is frequent. The entire department territory is subject to the phenomenon of frost, which lasts an average of 22 days a year (ANDI 2015).

\section{Socioeconomically}

The population of the region has strongly evolved during the various population censuses carried out since 1977 from 407,663 inhabitants to reach the number of 968,446 inhabitants in 2018 (DPSB 2018). Therefore, the population of the department of Mascara represents $1.2 \%$ of the Algerian population. The peri-urban commune of Mamounia is populated by approximately 16,506 inhabitants, with a density of 170 inhabitants/ 
$\mathrm{km}^{2}$. The forest/human interface is very important there because of the bursting of the habitat in the forest of Zakour, an agglomeration of 285 inhabitants.

\section{Methodological approach}

The methodological approach for the mapping of forest fire risk zones on the application of the model integrating GIS and remote sensing for the extraction, capture, processing and analysis of geographic information, aiming at the evaluation of parameters of the model, responsible for initiating, initiating and spreading forest fires and collecting data in the form of annual fire reports, requiring the integration of the following parameters:

- Combustibility index "CI" (types of vegetation, horizontal structure of the vegetation, nature of the fuel and degree of its flammability),

- Topo-morphological index "MI" (slope, exposure, altitude),

- human index "HI" or anthropogenic factors (human activity, distances to farms, distances to builtup areas near a built-up area and agricultural land use of land, pasture, road and douars or small village, etc.).

The intersection of the combustibility index layer, the topo-morphological index layer and the human occupation index led to the mapping of the potential risk of forest fires.

For the realisation of the forest fire risk map, we used the Turkish model adopted by Erten et al. (2004) and $\mathrm{Xu}$ et al. (2005). This model involves five factors: the type of vegetation (TV), the slope (S), the exposure (E), the distance from the roads (Dr) and the distance from the agglomerations (Da). The model applied is based on the following formula:

$$
\mathrm{RI}=7 \mathrm{TV}+5(\mathrm{~S}+\mathrm{E})+3(\mathrm{Dr}+\mathrm{Da})
$$

(Erten et al. 2004)

where:

RI - risk index of forest fire,

TV - type of vegetation,

$\mathrm{S}$ - slope,

E - exposure,

Da - distance from agglomerations (towns),

Dr - distance from roads.
In this study, we have adopted the model by its adaptability to Mediterranean regions and its simplicity of execution because "it is not too demanding in terms of data, especially for those relating to forest fires". The application of the model is closely related to the values in Table 1.

Table 1. Summary of the revised and adopted parameters for the model and their weights

\begin{tabular}{|c|c|c|c|c|c|c|}
\hline 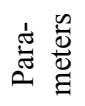 & 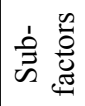 & $\begin{array}{l}\frac{5}{00} \\
.00 \\
3\end{array}$ & \multicolumn{2}{|c|}{ Classes } & 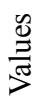 & $\begin{array}{c}\text { Risk } \\
\text { degrees }\end{array}$ \\
\hline 1 & 2 & 3 & \multicolumn{2}{|c|}{4} & 5 & 6 \\
\hline \multirow{7}{*}{ 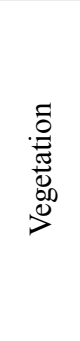 } & \multirow{3}{*}{$\begin{array}{l}\stackrel{2}{0} \\
\frac{0}{0} \\
\frac{0}{0}\end{array}$} & \multirow{3}{*}{7} & \multicolumn{2}{|c|}{ high density } & 3 & strong \\
\hline & & & \multicolumn{2}{|c|}{ average density } & 2 & medium \\
\hline & & & \multicolumn{2}{|c|}{ low density } & 1 & low \\
\hline & \multirow{4}{*}{ 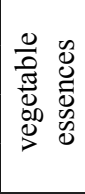 } & \multirow{4}{*}{7} & \multicolumn{2}{|c|}{ Quercus ilex } & 5 & very strong \\
\hline & & & \multicolumn{2}{|c|}{ Pinus halepensis } & 4 & strong \\
\hline & & & \multicolumn{2}{|c|}{ Olea europea } & 3 & medium \\
\hline & & & \multicolumn{2}{|c|}{ Pelouse } & 2 & low \\
\hline \multirow{5}{*}{$\begin{array}{l}\frac{0}{0} \\
0 \\
\frac{0}{0} \\
\frac{0}{n}\end{array}$} & & \multirow{5}{*}{5} & \multicolumn{2}{|c|}{$>35 \%$} & 5 & very strong \\
\hline & & & \multicolumn{2}{|c|}{$25-35 \%$} & 4 & strong \\
\hline & & & \multicolumn{2}{|c|}{$10-25 \%$} & 3 & medium \\
\hline & & & \multicolumn{2}{|c|}{$10-5 \%$} & 2 & low \\
\hline & & & \multicolumn{2}{|c|}{$<5 \%$} & 1 & very low \\
\hline \multirow{4}{*}{ 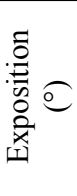 } & & \multirow{4}{*}{5} & south-west & $180-270^{\circ}$ & 4 & very strong \\
\hline & & & south east & $90-180^{\circ}$ & 3 & strong \\
\hline & & & north west & $270-360^{\circ}$ & 2 & medium \\
\hline & & & northeast & $0-90^{\circ}$ & 1 & low \\
\hline \multirow{5}{*}{ 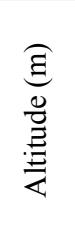 } & & \multirow{5}{*}{5} & \multicolumn{2}{|c|}{$<800$} & 5 & very strong \\
\hline & & & \multicolumn{2}{|c|}{$800-900$} & 4 & strong \\
\hline & & & \multicolumn{2}{|c|}{$900-1,000$} & 3 & medium \\
\hline & & & \multicolumn{2}{|c|}{$1,000-1,100$} & 2 & low \\
\hline & & & $>1$, & 100 & 1 & very low \\
\hline & & & $0-1$ & 00 & 5 & very strong \\
\hline & - & & 100 & -200 & 4 & strong \\
\hline$\Xi$ & ग्ञ & 3 & 200 & -500 & 3 & medium \\
\hline 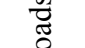 & 0 & & $500-1$ & 1,000 & 2 & low \\
\hline$\Xi$ & & & $>1$, & 000 & 1 & very low \\
\hline$\stackrel{0}{3}$ & & & 0 & & 5 & very strong \\
\hline 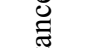 & $N$ & & $50-$ & 100 & 4 & strong \\
\hline .0 & $\frac{0}{0}$ & 3 & 100 & -200 & 3 & medium \\
\hline & & & 200 & -500 & 2 & low \\
\hline & & & $>5$ & & 1 & very low \\
\hline
\end{tabular}




\begin{tabular}{|c|c|c|c|c|c|}
\hline 1 & 2 & 3 & 4 & 5 & 6 \\
\hline \multirow{5}{*}{ 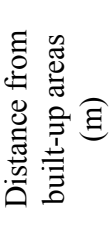 } & & \multirow{5}{*}{3} & $0-100$ & 5 & very strong \\
\hline & & & $100-500$ & 4 & strong \\
\hline & & & $500-1,000$ & 3 & medium \\
\hline & & & $1,000-2,000$ & 2 & low \\
\hline & & & $>2,000$ & 1 & very low \\
\hline \multirow{5}{*}{ 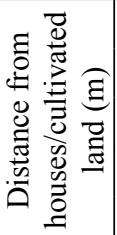 } & & \multirow{5}{*}{3} & $0-50$ & 5 & very strong \\
\hline & & & $50-100$ & 4 & strong \\
\hline & & & $100-400$ & 3 & medium \\
\hline & & & $400-1,000$ & 2 & low \\
\hline & & & $>1,000$ & 1 & very low \\
\hline
\end{tabular}

Erten et al. 2004; Raptis et al. 2012.

The use of this approach allows us to make a map of the risk of forest fires in a relatively short time and this, by integrating the different risk factors in their simplest form, especially with regard to vegetation.

Several authors have been used models to develop risk maps for forest fires in Algeria (Missoumi and Tadjerouni 2003; Belhadj 2003; Belhadj et al. 2003; Khader et al. 2009; Belat et al. 2012; Talbi et al. 2017; Chiali 2018; Talbi 2019).

Topo-morphological index $(\mathrm{S}+\mathrm{A}+\mathrm{E})$

Topography is an important physiographic factor closely related to the behaviour of wind, and which directly influences the predisposition of a region to fire, on which depend the behaviour of fires, detection. Three topographic parameters are involved in the start and spread of a forest fire: slope, exposure and altitude. Three topographic parameters are involved in the mod-

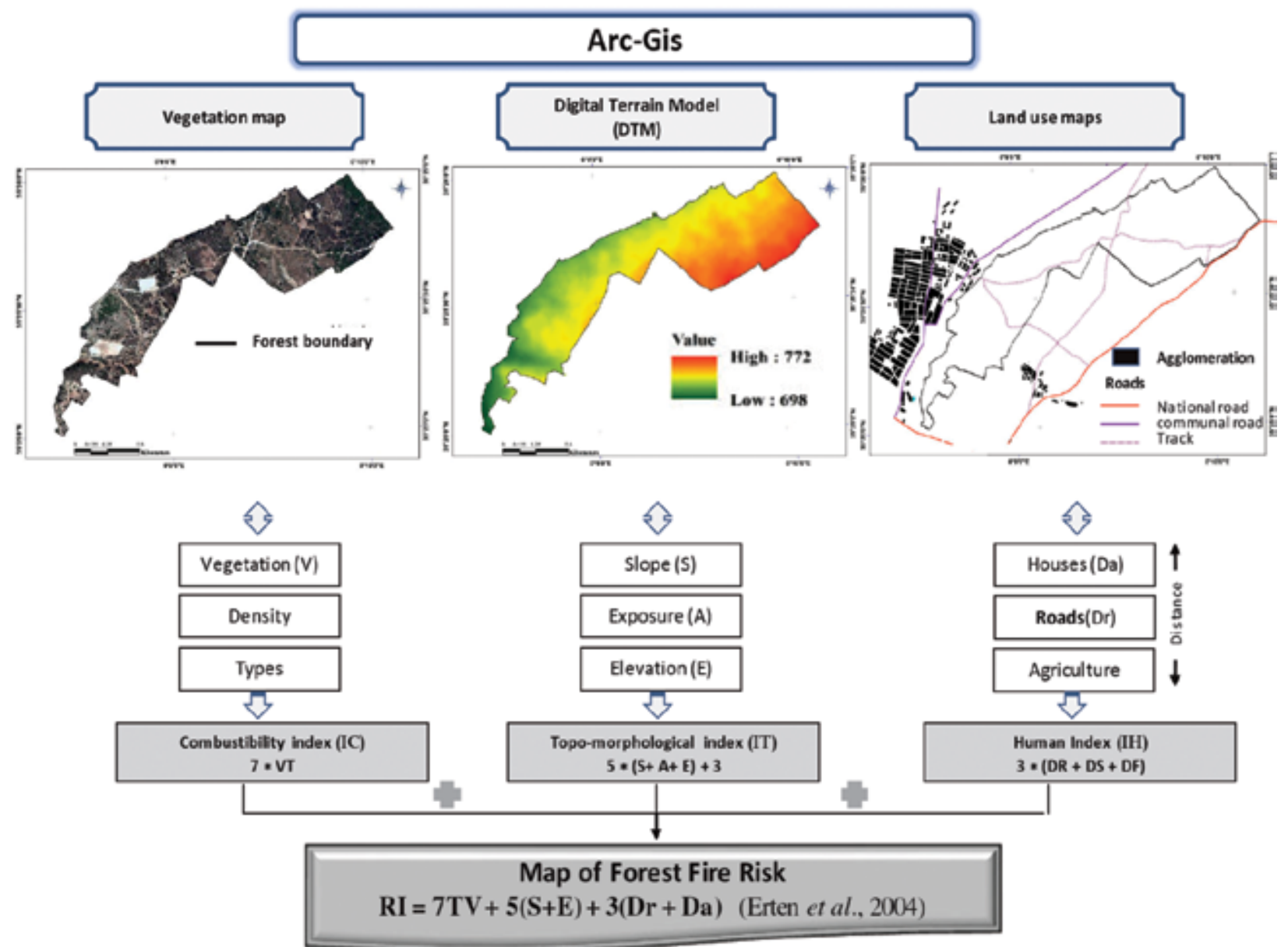

Figure 2. Flow chart of the methodological approach applied to draw up a fire risk map for the Zakour forest (Municipality of Mamounia) 
el: slope, exposure and altitude. All these parameters are deduced from the digital terrain model (DTM) of the study region (Fig. 2).

\section{Slope (S)}

It promotes the upward spread of fire between the burnt front and the vegetation still intact. Therefore, the more the slope is inclined, the higher the risk of fire spread. The calculation of the slopes from the digital elevation model (DEM) produces a raster format file, which must be classified according to Table 1 . In terms of forest fire, the effect of the slope is in the modification of the inclination of the flames relative to the soil, which promotes heat transfers to the vegetation located upstream. Consequently, the slope is steeper, the risk as the greater. This parameter also has an impact on the difficulty of accessibility for firefighting or so-called parades. The slope of the study site varies between 0 , for horizontal pixels, up to $75 \%$ for the most inclined areas. The latter are mainly located in the far east of the study area (Talbi 2019).

\section{Exposure (E)}

Throughout the northern hemisphere of the earth, a slope facing south finds itself facing the sun, and on the contrary, a north slope is shaded. This influences the temperature and humidity of the air, which influences the risk of hatching and spreading of fires. Calculating exposures from the DEM produces a raster that contains values expressed in degrees, with north as the origin. This raster file must be classified according to Table 1 (Talbi 2019).

\section{Elevation ( $E$}

The higher altitudes are linked to a greater availability of air freshness and probability of rain, and therefore, the risk of fire tends to be lower. The trend in fire behaviour will be less severe at high altitudes due to the possible heavy precipitation (Talbi 2019).

Human Index (RD + SD + FD)

The presence of the population and their homes near the forests is the issue, whose importance determines the degree of vulnerability of the environment. It is about protecting people and facilities. Thus, the anthropic parameter is the main term in the human activity index model. The anthropogenic factor, or indicator factor of human presence, has its weight and its direct influence in the outbreak of a forest fire and then and indirectly on its spread. This factor characterises the impact of infrastructure (roads, built-up area, villages, house and cultivated land) present in the immediate vicinity of forest areas. Their vulnerability is inversely proportional to the distance between them and these infrastructures. That is to say, the risk of forest fires decreases by moving a medium from anthropized areas. Thus, this parameter was divided into three sub-factors (Raptis et al. 2012): distance from roads, tracks (DR), distance from built-up areas and villages and distance from houses (DA) (Talbi 2019).

However, fire outbreaks are much more frequent near forest roads and paths. The closer you get to roads, dwellings (isolated houses or farms, villages and towns) and/or farmland, the higher the risk of fire. This risk decreases further from these areas. Therefore, the potential risk of a fire outbreak is closely linked to the proximity of these human infrastructures (Talbi 2019).

Vegetation index (VI)

The main factor, which affects the spread of a forest fire, is the type of vegetation (fuel) and its characteristics. To estimate and map the recovery rate of forest vegetation, we need to extract to another vegetation index (VI). Regarding the application of the model used, only the classes, with non-zero overlap, were retained: weak, medium and strong. This qualitative estimate materialises the potential risk of forest fires linked to vegetation (Tab. 1) (Talbi 2019).

Fire risk index (CR)

The fire risk mapping allows us to delimit the potential areas of fire outbreaks while being able to trace the causes and degree of the risk (highly flammable vegetation, high slope, proximity to a road, etc.). The fire risk calculation was carried out with the "map calculator" function of the analyst spatial extension. This involves applying the formula of the model adopted on the different vegetation, topo-morphological and human indices in raster format.

This modelling accounts for the complexity of this scourge and for the understanding and quantification of the physical and anthropogenic factors that govern it (Faleh et al. 2016).

This index is designed according to a model adopted under conditions specific to the study area; assigning 
a weighting coefficient to each parameter, depending on its influence on the spread of the fire (Hamdach and Bourazza 2016).

The approach used to produce the thematic information layers necessary for the creation of the fire risk map was carried out in several successive stages. The different stages of the methodology adopted throughout this work are represented by the flowchart summarised below (Fig.2).

\section{Results AND DISCUSSION}

The present work made it possible to draw up various index maps of the risks (Fig.3) linked to vegetation, topography, human presence as well as the proposal for improvements based on the results obtained.

\section{Vegetation index $(\mathrm{Cl})$}

The developed vegetation map (Fig. 4) enables the stands to be known and classified by major categories of combustibility and flammability of the plant species encountered in the study area. It indicates that $48.33 \%$ of the studied area presents a high risk (61.32 ha), the space involved brings together a forest and a scrub with a predominance of the Aleppo Pine species (Fig.5). These areas present a greater fire risk, while the medium-risk classes occupy $34.14 \%$ (43.21 ha) and the low-risk class occupies an area of $17.54 \%$ or $(22.25$ ha) of the study area (mainly bare soil). Charif et al. (2016), indicate that the response of vegetation to this scourge will make it possible to better undertake remedial actions helping the forest to recover.
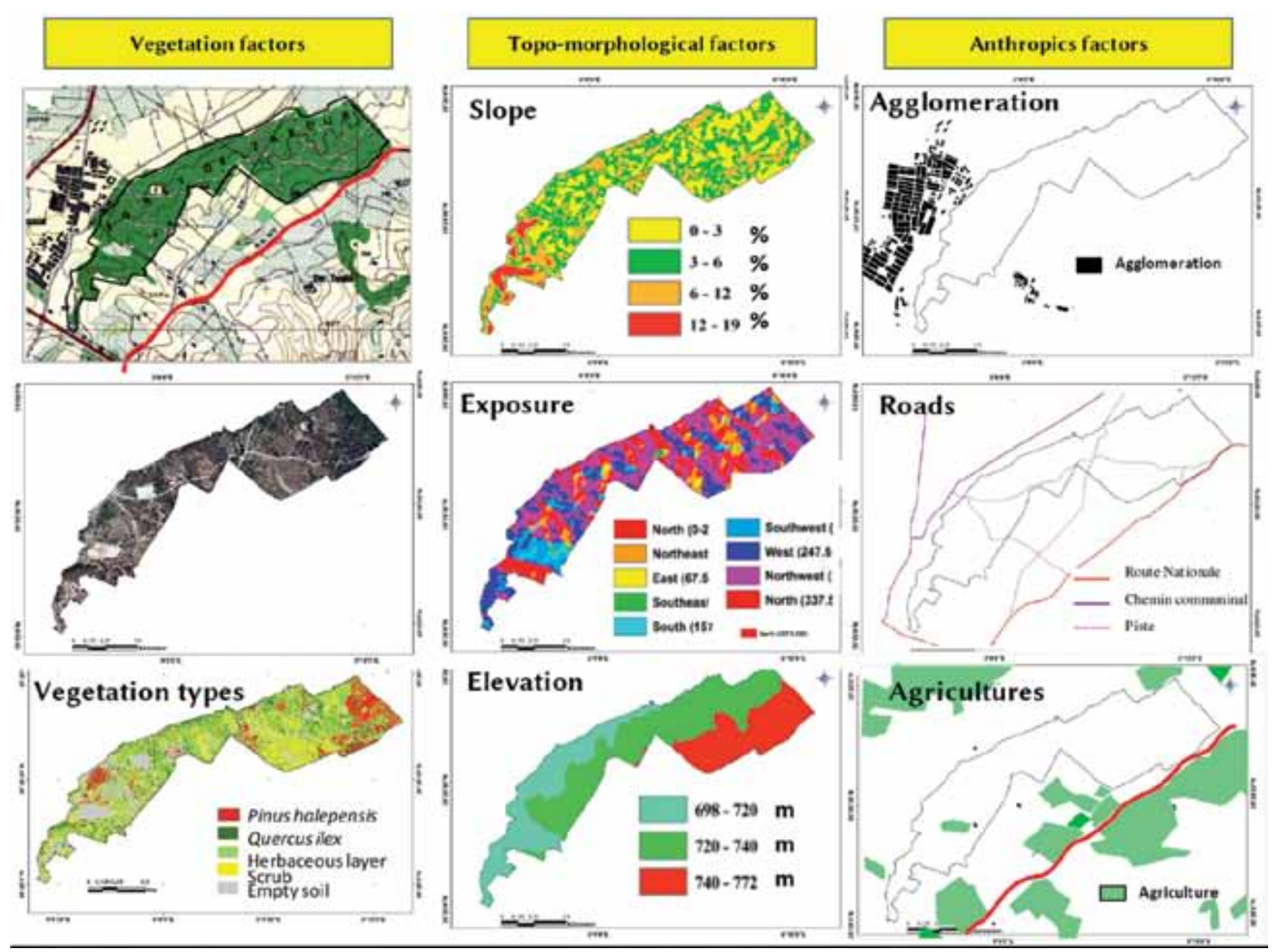

Figure 3. Fire risk factors 

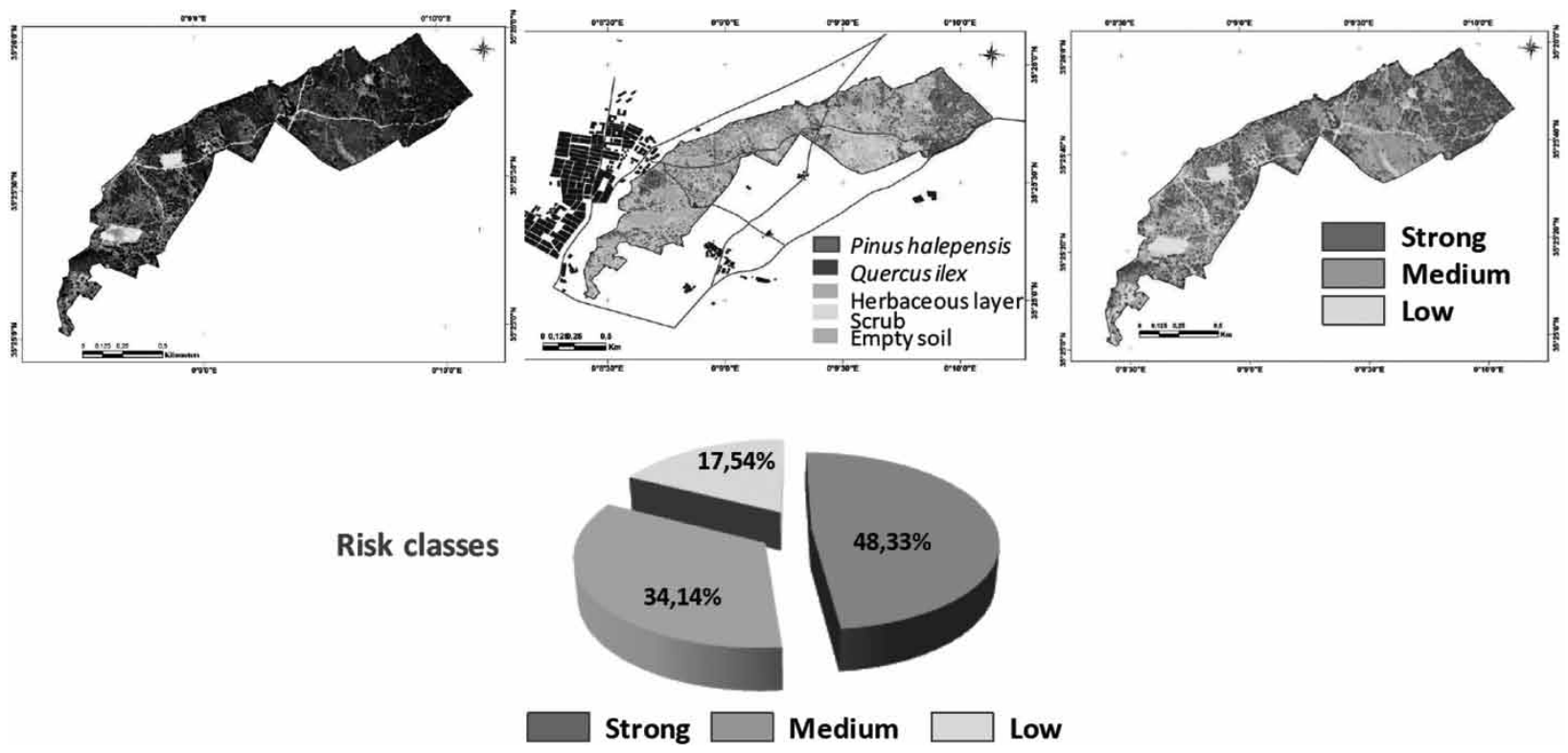

Figure 4. Combustibility risk map (CI) for the study area
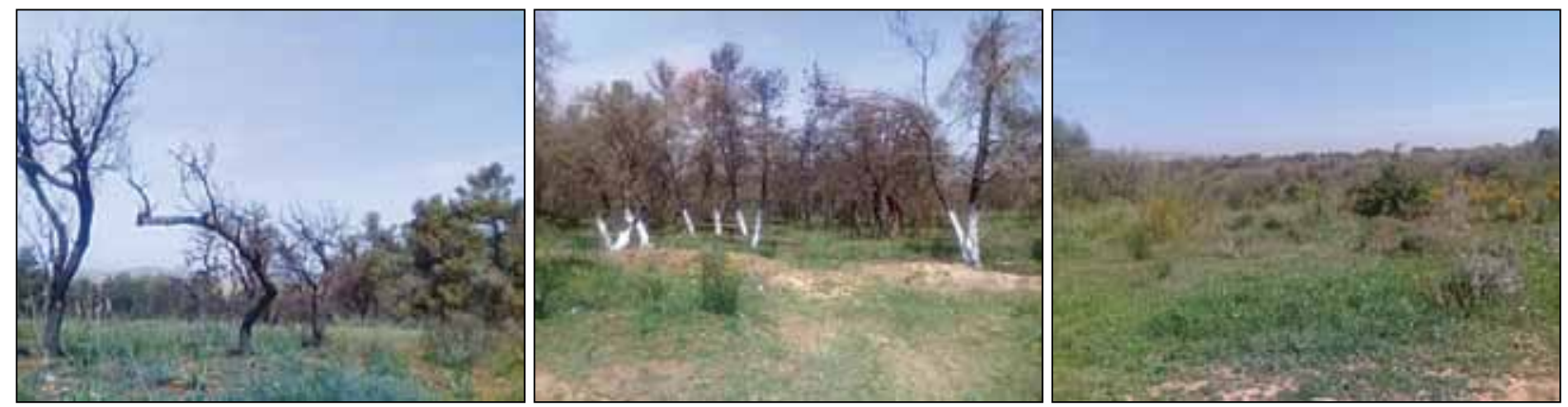

Figure 5. Vegetation types in the study forest (Cork oak, Aleppo pine, Brushwood)

\section{Topo-morphological index}

The risk of inflammation based on the degree of influence of several topo-morphological factors (slope, slope exposure and altitude).

\section{Slope}

The most represented classes are the low- and very-lowrisk class $92 \%$ of the study area (116.52 ha). These classes occupy almost the entire area, the medium-risk class, which represents $8 \%$ (10 ha). Generally, slopes are solid ground, valley bottoms and plateaus; these grounds have no risk of fire. The middle classes are characterised by hilly reliefs; those are plateaus or low hills. The slope plays a very important role in the spread of fire (Guettouche et al. 2011; Maktite et al. 2016).

\section{Exposure:}

Reading the exposure risk map of the study area (Fig. 6) shows us that the most widespread class is the high-risk class, which represents 55\% with an area of (69.6 ha) of the study area. This is mainly due to the fact that the study area is characterised by various exposures, the most dominant of which are the west and south exposure. The very-high-risk class represents $23.64 \%$ (29.92 ha) of the same area. On the other hand, the lowrisk classes represent $20.35 \%$ with an area of (25.75 ha), 

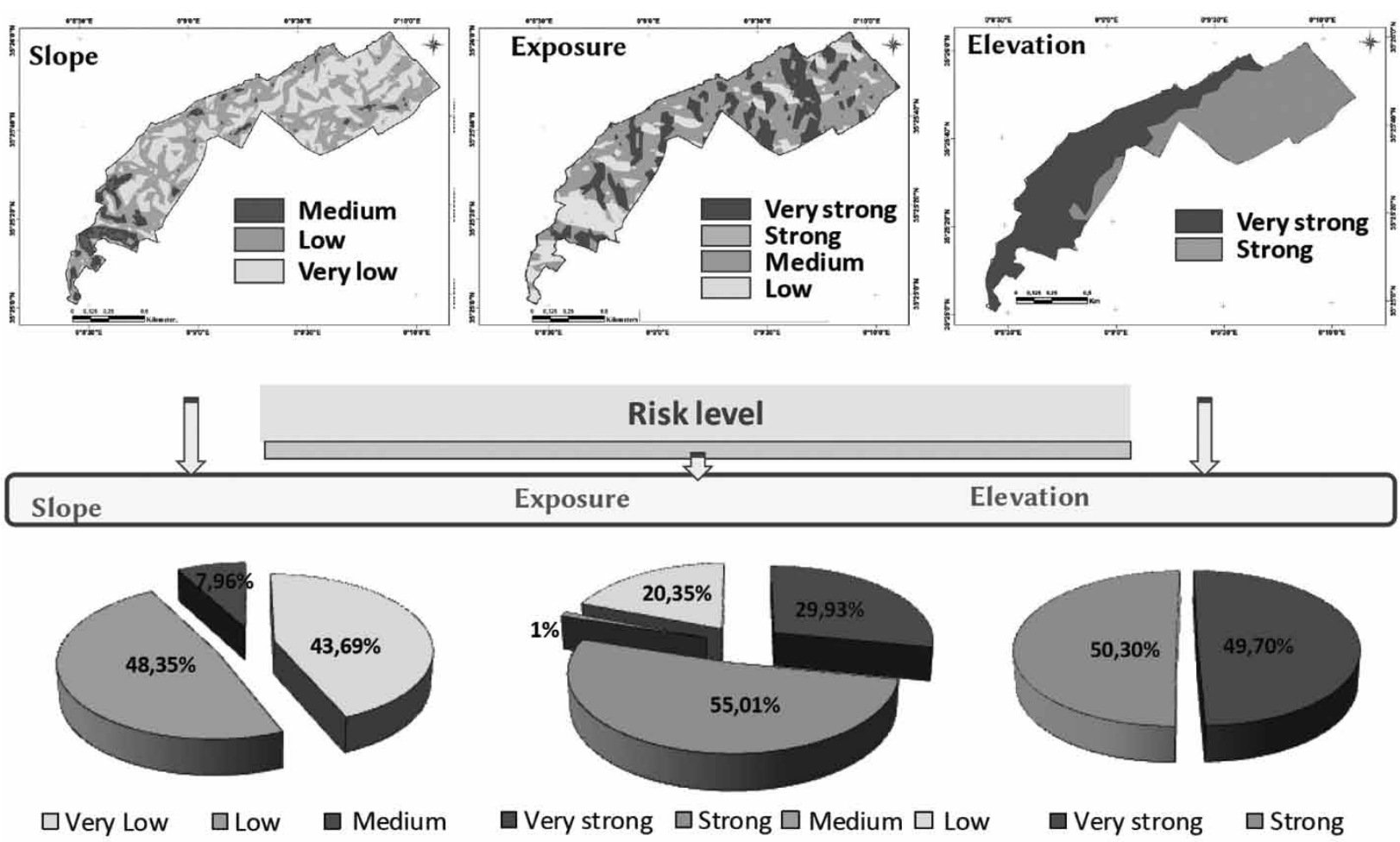

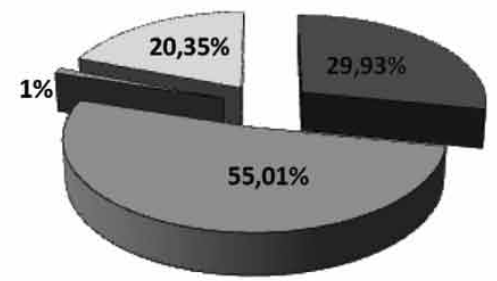

Very strong $\square$ Strong $\square$ Medium $\square$ Low
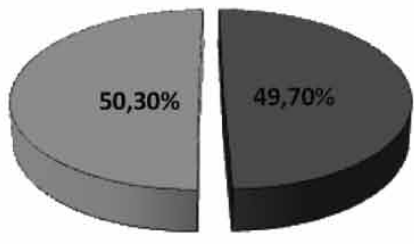

Very strong $\square$ Strong

Figure 6. Risk map of the topo-morphological index (IT) of the study area

and the medium risk classes represent only $1 \%$ with an area of (1.26 ha).

\section{Elevation (Altitude)}

We note that the high-risk class occupies the majority of the study area $(90 \%)$. This demonstrates, by Mekikite and Faleh (2017), that high altitude areas are favourable or even very favourable to the risk of fire by the presence of type trees with high caloric intensity.

\section{Human index (HI)}

The human index is retained as one of the factors for risk assessment. It is linked to human presence and activity (anthropogenic factors). This human index was characterised by the distances from roads, settlements, houses and/or agricultural land. These parameters impact the start of forest fires (Belkaid 2016; Medddour 2014; Faleh et al. 2016).
The proximity index of houses and agglomerations:

Figure $7 \mathrm{a}$ shows that over $44 \%$ of the study area presents a very high risk (proximity $<50 \mathrm{~m}$ ). However, the high-risk class (50 and $100 \mathrm{~m}$ ) represents $24.25 \%$ of the study area. This impact is justified because the Zakour Forest is closer to the population of the commune of Mamounia (less than $5 \mathrm{~km}$ ). Followed by the low-risk class ( $>500 \mathrm{~m}$ ), which occupies $33 \%$. For this purpose, the risk decreases the further we move a medium from these places. This no doubt reflects the role of human presence in the outbreak of fires.

Road proximity index:

A strong exerted pressure is due to the density of the roads around the forest of Zakour (Fig. 7). Therefore, these roads constitute a major factor of degradation because of the ease of access to the various resources of this forest.

Figure $8 \mathrm{~b}$ indicates that more than $43 \%$ of the study area presents a medium to high risk (proximity $<200 \mathrm{~m}$ ). However, the very-high-risk class (proxim- 

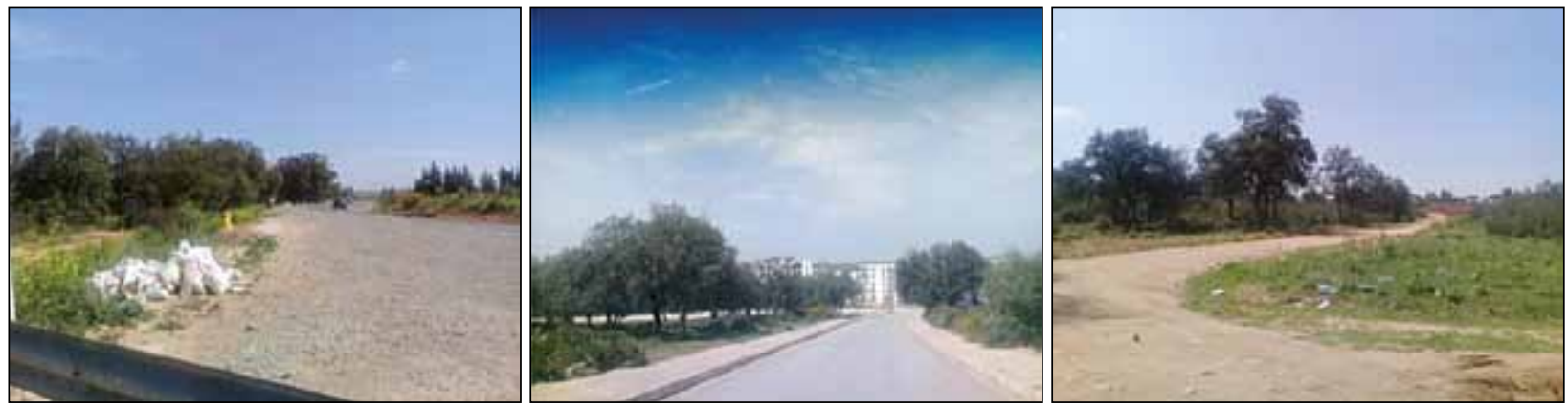

Figure 7. Impact of Roads on the Zakour Forest
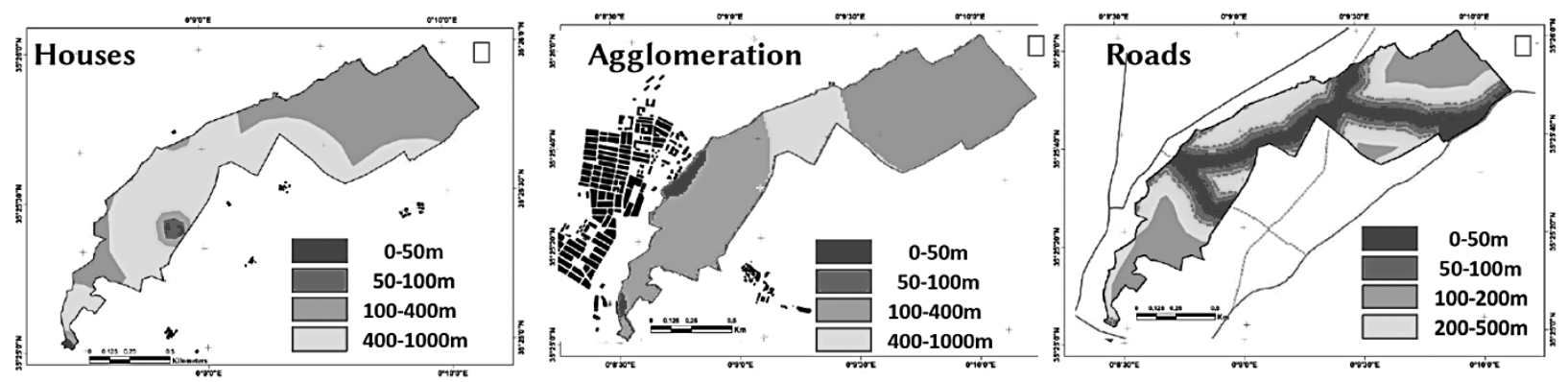

LEGEND: — Forest boundary

Distance $(\mathrm{m}): \square 50 \mathrm{~m}$

$100 \mathrm{~m}$

$200 \mathrm{~m}$

$>\mathbf{2 0 0} \mathrm{m}$

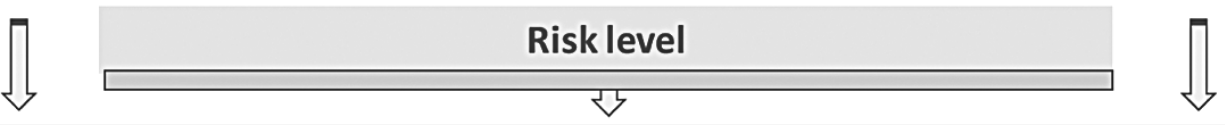

\begin{tabular}{|lll|}
\hline Houses & Agglomeration & Roads \\
\hline
\end{tabular}

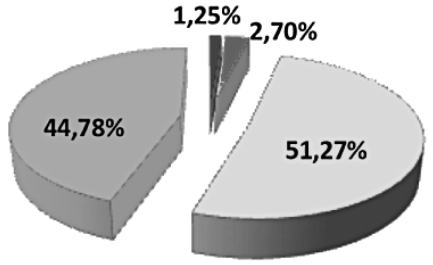

Risk classes

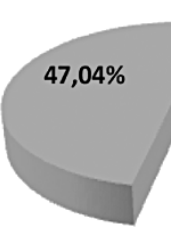

Very Strong

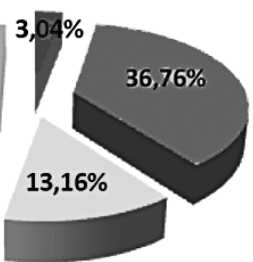

Strong

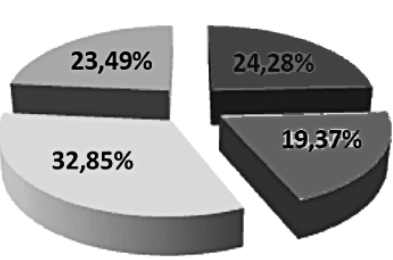

Medium
Low

Figure 8. Combustibility risk map (CI) for the study area

ity $<100 \mathrm{~m}$ ) represents $24.28 \%$ of the area of the study area. While, the low-risk class represents $33 \%$ (distance from the roads is more than $400 \mathrm{~m}$ ). For this purpose, the extent of the fire is noted especially at the edge of different roads. This is reported by Makikite and Faleh (2017) and Faleh et al. (2016) that most of the fire starts $(85 \%)$ are triggered around the tracks and roads.

The map of potential fire risk in the Zakour Forest (Fig. 9) shows a predominance of medium and high risk, with respectively ( $37 \%$ or 46.88 ha) and (33\% or $41.83 \mathrm{ha})$ of the surface total forest. The other classes are distributed as follows: low risk (17\% or $21.78 \mathrm{ha})$ and very high risk ( $12 \%$ or 16.31 ha) of the study area.

From this approach, sensitive areas in the Zakour Forest (Mamounia) are now well known and mapped. The results obtained show the significant extent of the risk of fire in the Zakour Forest. Good knowledge of the causes of forest fires has enabled us to act better on the 


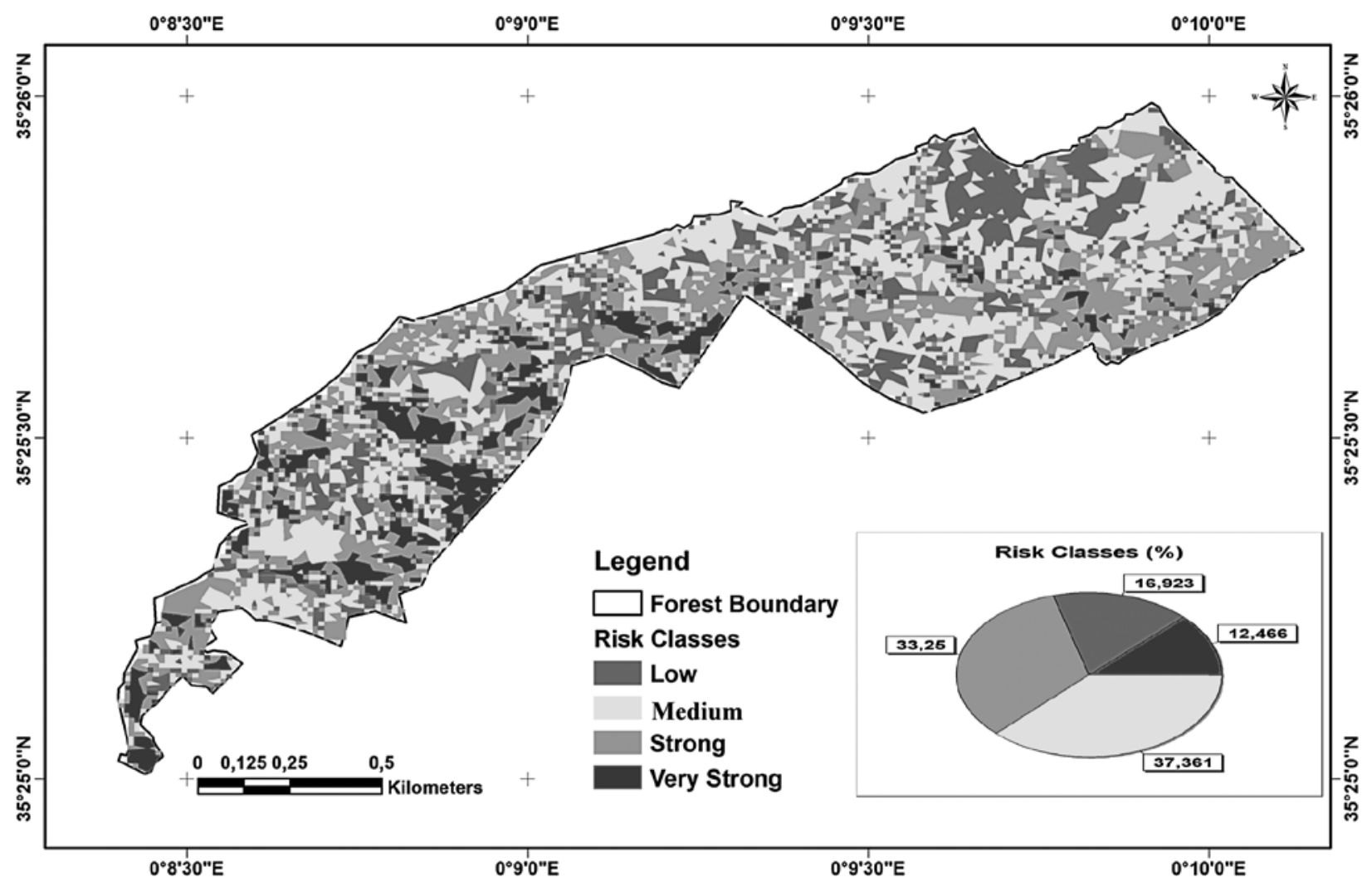

Figure 9. Map of potential fire risk in the Zakour Forest

actions to be taken in terms of prevention and to better reduce their effects. The anthropogenic and climatic factors seem to be involved in the outbreak of fires in the study area:

- The risk of forest fires is very influenced by the nature of the vegetation in combination with human and topo-morphological activities, given the value of the weight assigned to this parameter. However, this influence is reduced when there is a combination of several other parameters for the same zone. Also, it should be noted that the fires are located mainly at the borders of the forest massifs, privileged places of the start of a fire, before spreading thereafter towards the interior of the massif.

- Existence of consistency with the reality on the ground, because it was found that the classes at medium to very high risk are indeed the areas where the majority of fires were recorded.

- Geographical location of the Zakour Forest near the agglomeration, which is a few kilometres from the capital of the department of Mascara and a few hundred metres from the capital of the commune of Mamounia.

- Ease of access linked to the high density of the road network located around the Zakour Forest.

- The causal frequency of fire outbreaks in the Zakour Forest between 11 and $20 \mathrm{~h}$, especially during the period between June and October when the summer season intersects with the summer holidays. This is due to the fact that this period coincides with the hottest and driest season, thus favouring the development of forest fires (Arfa 2008).

- The pressure exerted by the high density of the preurban population, of the order of 74 inhabitants $/ \mathrm{km}^{2}$, testifies to an overexploitation of natural resources and especially the study forest.

- The floristic composition of the forest in highly combustible pyrophyte species, in particular: Aleppo pine (Pinus halepensis) and Holm oak (Quercus ilex). According to Talbi et al. (2017), the main factor affecting the spread of a forest fire is the type of vegetation and its characteristics. Aleppo pine is one of 
the major species of the Mediterranean region most affected by fire, xerophilic forest species with high flammability and combustibility belonging to the conifer family (Talbi et al. 2017). Thus, the structure and composition of plant formations dominated by coniferous species, accompanied by undergrowth where brushwood dominates, are all factors favouring forest fires (Missoumi et al. 2003; Chiali Charif 2018). According to Arfa (2008), the majority of Algerian forests is constituted by the presence of the pinnacles (based on Aleppo pine), remains the plant formation most affected by fires with more than $60 \%$ of the total area burned.

- The criminal and/or deliberate nature of a significant number of man-made fires, which can be explained by significant human pressure linked to tourist and leisure activities. The negligence of day trippers who light campfires and that of smokers is the cause of almost a third of fires (Vélez 1999). According to Chiali-Charif (2018), the causes of these fires are imputed to human activities (malicious or reckless, voluntary, social) with a rate that exceeds $65 \%$.

- The Mascara region is located in semi-arid areas where there are climatic fluctuations and long periods of drought. According to Velez (1999) and Marc et al. (2007), these climatic factors which increase and extend in time and in space cause the danger of fire.

- Deforestation due to the demand for cropland and pasture in certain regions. These agricultural activities are very famous in the Mascara region.

\section{Conclusion}

The forest of Zakour constitutes a space of great ecological and socio-economic interest for the population of the commune of Mamounia and the department of Mascara. Unfortunately, this heritage finds itself facing a serious threat of the most devastating fire in the forest.

The cartographic result made it possible to identify the parameters responsible for the outbreak of fires and to classify as accurately as possible the areas at risk of forest fires. This identification and classification of these parameters makes it possible to minimise their major effects. These are interesting and constitute a contribu- tion for a better prevention of forest fires and a certain decision aid.

In perspective, the cartographic documents produced constitute an essential means of decision-making in terms of forest management to intervene for the protection of areas sensitive to forest fires, with the aim of conserving and preserving this forest heritage for future generations. Therefore, it is necessary, for the success of such a management action to fight forest fires, to involve and sensitise the populations near the forests in actions aimed at preventing any outbreak of fire.

\section{References}

Alexandrian, D. 2008. Les statistiques "feux de forêt" de ces trente dernières années. Forêt Méditerranéenne, 29 (4), 377-384.

ANDI (Agence Nationale de Développement de l'Investissement ANDI). 2015. Wilaya de Mascara.

Arfa, A.M.T. 2008. Les incendies de forêt en Algérie: Stratégies de prévention et plans de gestion. Mémoire de Magistère en Ecologie et Environnement. Option : Ecologie végétale. Département de biologie et écologie. Faculté des sciences de la nature et de la vie. Université Mentouri Constantine.

Arfa, A.M.T., Benderradji, M.H., Alatou, D. 2009. Analyse des Bilans des incendies de Forêt et leur Impact Economique en Algérie entre 1985 et 2006. New Medit, 1, 46-51.

Arfa, A.M.T., Benderradji, M.H., Saint-Gérand, T., Alatou D. 2019. Cartography of wildfire hazards in Northeast Algeria: the Tarf Province as a case study. European Journal of Geography, DOI: https://doi.org/10.4000/cybergeo.32304

Belat, F., Janisset, J., Tinel, B., Specque, H. 2012. Miniprojet tuteuré: Outils de prévention de risques de feux de forêt. Semestre 2, Université Paul-Valery de Montpelier.

Belhadj-Aissa, A. 2003. Application du SIG et de la télédétection dans la gestion des feux de forêts en Algérie. CNTS d'Arzew.

Belhadj-Aissa, M., Belhadj-Aissa, A., Smara, Y. 2003. Application du SIG et de la télédétection dans la gestion des feux de forêts en Algérie. 2nd FIG Regional Conference, Marrakech, Morocco, December 2-5. 
Belkaid, H. 2016. Spatial and environmental analysis of forest fire risk in Algeria: Case of maritime Kabylie. Doctoral thesis. Université de Nice, France. Benderradji, M.H., Alatou, D., Arfa, A.M.T., Benachour, K. 2006. Problèmes de dégradation de l'environnement par la désertification et la déforestation Impact du phénomène en Algérie. New Medit, 4, 19-21.

Benabdeli, K. 2014. Quels indicateurs pour la compréhension et la gestion des facteurs de perturbation des écosystèmes forestiers en zone aride. Séminaire Maghrébin sur la dynamique et la valorisation des écosystèmes arides et semi-arides dans un environnement changeant. Saïda 21-22 octobre 2014.

Benhanifia, K., Haddouche, I., Bensaid, A., Smahi, Z., Hamimed, A. 2004. Characterization of the deforestation effect in a semi-arid region by the use of satellite images. Remote Sensing for Agriculture, Ecosystems, and Hydrology V. Proceedings of the SPIE, 5232, 324-332.

Bensouiah, R. 2004. Politique forestière et lutte contre la désertification en Algérie. Du barrage vert au PNDA. Forêt Méditerranéenne, 25 (3), 191-198.

Berrichi, M., Benabdeli, K., Letreuch-Belarouci, N., Haddouche, I. 2013. Forest fires in Algeria: points of view of school children and political prevention. Mediterranea. Serie de Estudios Biológicos, 24, 132-160. DOI: 10.14198/MDTRRA2013.24.05

Berchiche, T. 1986. Contribution à l'étude socioéconomique de la forêt algérienne. Thèse magister. Science agronomique: INA d'Alger.

CF Mascara. 2019. Bilan des incendies dans la wilaya de Mascara.

Charif, K., Benabdeli, K., Belgharbi, B. 2016. Analyse $\mathrm{du}$ comportement des principaux groupements forestiers face aux incendies dans le massif forestier de Telagh, Algérie. Afrique Science, 12 (1), 39-49.

Chiali Charif, K. 2018. Contribution à une étude des incendies de forêts dans le massif de Télagh (Algérie occidentale). Thèse de Doctorat En Sciences Environnement Option: Pathologie des Ecosystèmes Terrestres. Universite Djillali Liabes Faculte Des Sciences Sidi Bel Abbes.

Dagorne, A., Duche, Y., Castex, J.M., Ottavi, J.Y., Dallier Ch. et De Coster A. 1994. Protection des forêts contre les incendies et système d'information géographique: application à la commune d'Auribeau -sur-Siagne (Alpes Maritimes). Forêt Méditerranéenne, 15 (4), 409-420.

D.G.F. 2018. Les feux de forêts en Algérie: Analyse et perspectives.

Dimitrakopoulos, A.P., Mitsopoulos, I.D. 2006. Global forest resources assessment 2005. Report on fires in the Mediterranean Region. Working paper FM/8/E, Forestry Department, FAO, Rome.

Erten, E., Kurgun, V., Musaoglu, N. 2004. Forest fire risk zone mapping from satellite imagery and GIS case study. XXth ISPRS Congress, Youth Forum, July 12-23, 2004, Istanbul, Turkey, 33-39.

Faleh, A., Hanchane, M., Chaaouan, J., Lakhouaja, E. 2016. Application d'un modele sig pour la modelisation du risque de feu de forets au moyen atlas oriental (commune rurale de bouchfaa - province de Taza-Maroc). 3ème Edition du Colloque International des utilisateurs du SIG. Acte de The 3rd International conference of GIS User. Oujda 22-23 Novembre 2016, 192-197.

FAO. 2007. Situation des forets du monde. Partiel, $64-72$.

FAO. 2013. Etat des forêts méditerranéennes 2013.

Ferka Zazou, N. 2006. Impact de l'occupation spatiotemporelle des espaces sur la conservation de l'écosystème forestier. Cas de la commune de Tessala, wilaya de Sidi bel Abbes, Algérie.

Ghennai, N. 2015. Etude des rapports et des corrélations entre le régime bioclimatique et les incendies de forets (cas de l'est-algérien). Séminaire international sur la gestion et l'aménagement durable des écosystèmes forestiers méditerranéens Les Acte de 08 et 09 décembre 2015.

Gouiran, M. 1999. Bilan des dégâts causés par les incendies de forêts dans les pays riverains de la méditerranée (1981-1997): pour la création d'un système d'information sur les incendies de forêts. Atelier "Les bases de données sur les feux de forêts en région méditerranéenne, utilisations et enseignements", 27 avril - 1er mai 1999, Tétouan, Maroc, 157-176.

Guettouche, M.S. et al. 2011. Modélisation du risque d'incendie de forêts et Validation par Approche Géomatique. Application sur la Forêt du Sahal Algérois, (Algérie). Congrés International GéoTunis, 29 Novembre - 3 Décembre 2010. 
Haddouche, I., Benhanifia, K., Gacemi, M. 2011. Spatial analysis of forest regeneration after fire in the forest of Fergoug in Mascara, Algeria. Bois et Forêts des Tropiques, 307 (1), 23-31.

Hamdach, Y., Bourazza, Z. 2016. SIG et modelisation des facteurs de risque d'incendie de foret (cas de la foret de Berkine, Guercif, Maroc). 3ème Edition du Colloque International des utilisateurs du SIG. Acte de The 3rd International conference of GIS User. Oujda 22-23 Novembre 2016, 186-191.

Jappiot, M., Blanchi, R., Alexandrian, D. 2003. Cartographie du risque d'incendie de forêt besoins, méthodes et données Essai de normalisation. Forêt Méditerranéenne, 24 (4), 427-434.

Khader, M., Benabdeli, K., Mederbal, K., Fekir, Y., Gueddim, R., Mekkous, B. 2009. Etude du risque incendie à l'aide de la géomatique: cas de la forêt de Nesmoth (Algérie). Mediterranea. Serie de Estudios Biológicos, 20, 205-234. DOI: 10.14198/ MDTRRA2009.20.07

Laala, A. 2016. Cartographie de la variabilité thermique des écosystèmes forestiers de l'Est algérien. These de docteur en sciences. Filière: Ecologie végétale. Option: Ecophysiologie et biotechnologie végétale. Département de biologie et écologie végétale. Faculté des sciences de la nature et de la vie, Université des frères Mentouri Constantine.

Louni, D. 1994. Les forêts algériennes. Forêt Méditerranéenne, 15 (1), 59-63.

Maddou. 2016. Le contexte des feux de forets dans le bassin méditerranéen. Guide technique en environnement, ecologie et developpement durable, 1-5.

Madoui, A. 2002. Les incendies de forêt en Algérie. Historique, bilan et analyse. Forêt Méditerranéenne, 23 (1), 23.

Madoui, A. 2013. Les incendies de forêts en Algérie. Étude de l'évolution après feu des peuplements de Pinus halepensis Mill. dans l'Est algérien. Cas de la forêt de Bou-Taleb, du reboisement de Zenadia et du parc national d'El Kala. Thèse de doctorat, université de Sétif.

Maktite, A., Faleh, A. 2017. Cartographie des zones à risque d'incendies de forêts à l'aide Du SIG et la télédétection dans l'arrière-pays du port Tanger Med. European Scientific Journal, 13 (32), 205-224.

Maktite, A., Faleh, A., Lakhouaja, E. 2016. Cartographie des zones a risque des incendies des forets a l'aide du SIG et la télédétection dans l'arrière pays du port Tanger Med. 3ème Edition du Colloque International des utilisateurs du SIG. Acte de The 3rd International conference of GIS User. Oujda 22-23 Novembre 2016, 233-238.

Marc, B., Despina, K., Pavlos, K., Nikos, P. 2007. A decision support system for managing forest fire casualties. Journal of Environmental Management, 84, 412-418.

Martinez, J., Martin, P. 2004. Los incendios forestales en en España. Analysisi de incidencias y causalidad. Nuevas tecnologias para la estimacion del riesgo de incendios foresteles. Colection de estudios ambiantales y socioeconomicos. Concejo Superior de Investigaciones Cientificas, 11-22.

Medddour, O. 2014. Forest fires in Algeria: risk analysis, causes study, evaluation of defence system and management policies. Thèse de Doctorat en Sciences Agronomique, option: foresterie.

Meddour-Sahar, O. 2008. Contribution à l'étude des feux de forêts en Algérie : approche statistique exploratoire et socio-économique dans la wilaya de Tizi Ouzou. Thèse de Magister, Ina El Harrach.

Meddour-Sahar, O., Bouisset, C. 2013. Les grands incendies de forêt en Algérie: problèmes humains et politiques publiques dans la gestion des risques. Méditerranée, 121, 33-40.

Meddour-Sahar, O., Meddour, R., Derridj, A. 2008. Analyse des feux de forêts en Algérie sur le temps long (1876-2007). Les notes d'analyse du CIHEAM, 39, $1-11$.

Mezali, M. 2003. Forum des Nations Unies sur les forêts (3ème session, Genève). Alger: Ministère de l'Agriculture et du Développement Rural et Direction Générale des Forêts.

Mezrag, D., Ziane, M. 2013. Les incendies des forets en algerie et leurs impacts sur l'environnement. Géotunis 2013.

Mihi, A. 2012. La forêt de Zenadia (Haute Plaine Sétifienne): Diagnostic et perspective de protection. Memoire de Magister Option: Biodiversité et gestion des écosystèmes. Département de biologie et écologie végétale, Université Ferhat Abbas de Sétif.

Missouni, A., Mederbal, K., Benabdelli, K. 2002. Apport des systèmes d'information géographiques dans la prévention et la lutte contre les incendies de 
forêts : Exemple de la forêt de Kounteidat, Algérie. Forêt Méditerranéenne, 23 (1), 1-11.

Missoumi, A., Tadjerouni, K. 2003. SIG et imagerie Alsatl pour la cartographie du risque d'incendie de forêt (Sidi Bel Abbes) TS13 Risk Management, Marrakech, Moroc.

ONS (Office National des Statistiques). 2015. Statistiques sur l'environnement. Collections Statistiques 177/2015. Série C : Statistiques Régionales et Cartographie; Statistiques sur l'Environnement. La Direction Technique Chargée des Statistiques Régionales et de la Cartographie, Alger.

Raptis, I.D., Zagas, T.D., Karamanolis, V.D., Zagas, D. 2012. Wildfire risk zone mapping in Olympus MT as a tool for silvicultural interventions in a forest management framework. Conference on Protection and Restoration of the Environment XI, 1110-1119.

Sahar, O., Leone, V., Limani, H., Rabia, N., Meddour, R. 2018. Wildfire risk and its perception in Kabylia (Algeria). iForest, 11, 367-373.
Souidi, Z., Benbakar, H. 2017. L'Algerie: une region mediterraneene tres sensible aux incendies de foret. Territorium, 24, 177-186.

Talbi, O. 2019. Contribution à la mise en place d'un Système d'Information Géographique pour la prévention des feux de forêts dans la région de Saïda. Thèse de Doctorat Ès Sciences, Option: Foresterie. Département des ressources forestières. Faculté des Sciences de la Nature et de la Vie et des Sciences de la Terre et de l'Univers. Université Abou Bekr Belkaid de Tlemcen.

Talbi, O., Benabdeli, K., Benhanifia, K., Haddouche, I. 2017. Cartographie des zones de risque de feux de forêt dans la commune de Doui Thabet, Saïda, Algéri. International Journal of Environmental Studies, 1-10. DOI:10.1080/00207233.2017.1386434

Vélez, R. 1999. Protection contre les incendies de forêt: principes et méthodes d'action. Options Méditerranéen: Série B. Etudes et Recherches, 26, 1-18.

$\mathrm{Xu}$, D., Dai, L.M., Shao, G.F. 2005. Forest fire risk zone mapping from satellite images and GIS for Baihe Forestry Bureau, Jilin, China. Journal of Forestry Research, 16 (3), 169-174. 